PRACE NAUKOWE UNIWERSYTETU EKONOMICZNEGO WE WROCLAWIU

Finanse i rachunkowość na rzecz zrównoważonego rozwoju -

ISSN 1899-3192

edukacja, etyka, innowacje. Finanse

e-ISSN 2392-0041

\title{
Ewa Dziawgo
}

Uniwersytet Mikołaja Kopernika w Toruniu

e-mail: dziawew@umk.pl

\section{REALIZACJA STRATEGII „EUROPA 2020" \\ W KRAJACH UNII EUROPEJSKIEJ}

\section{IMPLEMENTATION OF "EUROPE 2020" STRATEGY IN THE COUNTRIES OF THE EUROPEAN UNION}

DOI: $10.15611 / \mathrm{pn} .2017 .478 .13$
JEL Classification: Q01, Q50

\begin{abstract}
Streszczenie: W polityce Unii Europejskiej ważne miejsce zajmuje realizacja Strategii „Europa 2020". Jest to długookresowy program rozwoju społeczno-gospodarczego Unii Europejskiej, którego głównym celem jest wdrażanie idei inteligentnego, zrównoważonego i sprzyjającego włączeniu społecznemu rozwoju. Celem artykułu jest porównanie stanu realizacji Strategii „Europa 2020” w krajach Unii Europejskiej. Analiza przeprowadzona jest dla lat 2010 i 2014. Przedmiotem badań są państwa Unii Europejskiej. Do osiągnięcia wyznaczonego celu zastosowano metodę wielowymiarowej analizy porównawczej. W wielu krajach Unii Europejskiej widoczna jest poprawa wyników w obszarze realizacji Strategii „Europa 2020”.
\end{abstract}

Słowa kluczowe: wzrost zrównoważony, ochrona środowiska, Strategia „Europa 2020”.

Summary: The implementation of "Europe 2020" Strategy is very important to the policy of the European Union. "Europe 2020" Strategy is the long-term programmeof the social andeconomic development for the European Union. The aim of the study is to compare the present state in the implementation of strategy policy in the countries of the European Union. The analysis is carried out for year 2010 and 2014. The countries of the European Union are an object of research. A lot of countries of the European Union have clearly improved their results in the area of the implementation of "Europe 2020" Strategy.

Keywords: sustainable development, environmental protection, “Europe 2020” Strategy.

\section{Wstęp}

Strategia „Europa 2020” jest długookresowym programem rozwoju społeczno-gospodarczego Unii Europejskiej, którego głównym celem jest wdrażanie idei inteligentnego, zrównoważonego i sprzyjającego włączeniu społecznemu rozwoju [Europe 2020 ... 2010]. W wyniku realizacji tej strategii w krajach Unii Europejskiej ma powstać niskoemisyjna gospodarka bazująca na wiedzy, w której: 
- $\quad$ promowane i stosowane są bardziej przyjazne środowisku technologie,

- występuje bardziej oszczędne gospodarowanie zasobami,

- kreowane są ,zielone” miejsca pracy,

- zachowywana jest dbałość o spójność społeczną.

W roku 2020, w wyniku wdrożenia strategii „Europa 2020” w krajach UE, powinny zostać osiągnięte następujące cele:

- wskaźnik zatrudnienia osób w przedziale wiekowym 20-64 wzrośnie do poziomu $75 \%$,

- na inwestycje w badania i rozwój będzie przeznaczane 3\% PKB,

- w porównaniu z rokiem 1990 emisja gazów cieplarnianych zmniejszy się o 20\% (a nawet o $30 \%$ ),

- udział energii odnawialnej w ogólnym zużyciu energii zwiększy się do 20\%,

- efektywność energetyczna zwiększy o 20\%,

- podniesiony zostanie poziom wykształcenia społeczeństwa poprzez zmniejszenie odsetka osób zbyt wcześnie kończących naukę (do poniżej 10\%) oraz zwiększenie odsetka osób w wieku 30-34 lata z wykształceniem wyższym (do co najmniej 40\%),

- zmniejszy się ubóstwo i wykluczenie społeczne (poprzez wydźwignięcie z ubóstwa co najmniej $20 \mathrm{mln}$ ludzi).

17 czerwca 2010 r. Rada Europejska zatwierdziła realizację długookresowego programu „Europa 2020”. Państwa członkowskie Unii Europejskiej pomimo swego zróżnicowania realizują wyznaczone cele, zmierzając w kierunku zielonej gospodarki. Obecnie można dokonać analizy realizacji tego programu przez poszczególne kraje UE.

Celem artykułu jest porównanie realizacji Strategii „Europa 2020” w krajach UE. Analiza przeprowadzona została dla lat 2010 i 2014. Ilustracja empiryczna zaprezentowana $\mathrm{w}$ artykule powstała $\mathrm{w}$ wyniku zastosowania wielowymiarowej analizy porównawczej [Hellwig 1968] ${ }^{1}$. Syntetyczny wskaźnik realizacji Strategii „Europa 2020"wyznaczono na podstawie szczegółowych czynników ${ }^{2}$ monitorujących wdrażanie założeń strategii. Na podstawie obliczonego syntetycznego wskaźnika stworzono ranking państw UE w realizacji założeń Strategii „Europa 2020”.

\section{Priorytety Strategii „Europa 2020"}

Irracjonalna działalność człowieka wobec przyrody jest przyczyną degradacji środowiska naturalnego. Pojawienie się niebezpieczeństwa globalnej katastrofy ekologicznej jest efektem pośredniej lub bezpośredniej ingerencji człowieka w ekosystemy. Wzrost natężenia niekorzystnych zjawisk dotyczy m.in.: efektu cieplarnianego, utraty różnorodności biologicznej, zmniejszania się zdolności planety do absorpcji

\footnotetext{
${ }^{1}$ W metodzie porządkowania liniowego Hellwiga punktem odniesienia obiektów jest wzorzec.

${ }^{2}$ Wskaźniki zostały określone przez Komisję Europejską.
} 
zanieczyszczeń i odpadów [Poskrobko 1998; Piontek i in. 2002; Blengini i in. 2012; Brouhle i in. 2013; Dziawgo 2014; Figge, Hahn 2012; The state of Nature in the European Union 2014].

Jednym z priorytetów Unii Europejskiej jest przeciwdziałanie negatywnym skutkom oddziaływania procesów gospodarczych na środowisko naturalne poprzez wdrażanie założeń polityki redukcji emisji gazów cieplarnianych, zrównoważonego wykorzystania energii oraz wykorzystywania odnawialnych źródeł energii [Ten priorities for Europe 2015; The European Union climate action 2014]. Unia dąży do stworzenia gospodarki przodującej w dziedzinie technologii środowiskowych i ochrony środowiska naturalnego. Realizując założenia strategii „Europa 2020”, kraje członkowskie UE zmierzają do redukcji emisji gazów cieplarnianych o $20 \%$ (a nawet o 30\%, w porównaniu z poziomem z $1990 \mathrm{r}$.) przy równoczesnym zwiększeniu wydajności energetycznej o 20\% i ilości zużywanej energii ze źródeł odnawialnych również o $20 \%$. Cel obniżenia konsumpcji energii pierwotnej osiągany jest m.in. przez systematyczną poprawę efektywności energetycznej procesów wytwarzania i użytkowania energii [Hinrichs-Rehlwes 2013; Jänicke 2012].

Kolejnym priorytetem realizowanym przez kraje UE w ramach wdrażania założeń strategii „Europa 2020” jest wzrost inteligentny, czyli rozwój gospodarki opartej na wiedzy i innowacji. Wzrost ten wymaga znacznych nakładów na badania i rozwój oraz stosowania mechanizmów, które umożliwią szybki transfer wiedzy teoretycznej do praktyki gospodarczej [Dziawgo, Dziawgo 2016; Common, Stagl 2005; Coddington 1993; Stern 2007; Yi 2013]. Niemożliwe jest stworzenie gospodarki opartej na wiedzy bez odpowiednio wykształconego społeczeństwa. Dlatego priorytet ten wymaga podniesienia jakości poziomu edukacji. Zgodnie z wytycznymi, państwa członkowskie powinny dokonać niezbędnych inwestycji we wszelkie systemy kształcenia, aby zwiększyć ich skuteczność i wydajność w podwyższaniu poziomu umiejętności oraz kompetencji siły roboczej. W celu wdrażania inteligentnego rozwoju konieczne jest również pełne wykorzystywanie technologii informacyjno-komunikacyjnych. Innowacyjne pomysły i projekty w obszarze rozwiązywania takich problemów, jak: zmiany klimatu, efektywność energetyczna, zdrowie, przyjazne środowisku metody produkcji, powinny być jak najszybciej przekształcane w nowe produkty i usługi.

Priorytetem Unii Europejskiej jest również realizacja wzrostu sprzyjającego włączeniu społecznemu. Komisja Europejska w tej dziedzinie wspiera i uzupełnia politykę poszczególnych państw członkowskich. Jednym z celów jest wydźwignięcie z ubóstwa i wykluczenia społecznego co najmniej 20 mln ludzi i zwiększenie do poziomu $75 \%$ zatrudnienia osób w wieku 20-64 lata. Zgodnie z wytyczną działań na rzecz włączenia społecznego, zwalczania ubóstwa i promowania równych szans państwa członkowskie powinny modernizować systemy zabezpieczenia społecznego. Systemy te winny wspierać ochronę i inwestycje w kapitał ludzki, w większym stopniu zachęcać ludzi do aktywnego uczestnictwa w rynku pracy i w społeczeństwie. W tym obszarze istotna jest dostępność wysokiej jakości i przystępnych ceno- 
wo usług, takich jak: opieka nad dziećmi, opieka pozaszkolna, kształcenie, szkolenia, usługi zdrowotne i opieka długoterminowa.

Realizacja wytyczonych celów określa kierunek ścieżki rozwoju Europy: zbudowanie zrównoważonej przyszłości naszego społeczeństwa.

\section{Analiza realizacji Strategii „Europa 2020” w krajach Unii Europejskiej}

W celu porównania realizacji założeń Strategii „Europa 2020” przez poszczególne państwa stworzono syntetyczny wskaźnik, który wyznaczony został na podstawie szczegółowych czynników monitorujących wdrażanie strategii. Wyodrębniono trzy obszary realizacji strategii:

- obszar klimatu i energii,

- obszar wzrostu inteligentnego,

- obszar wzrostu sprzyjającego włączeniu społecznemu.

W obszarze klimatu i energii zastosowano następujące wskaźniki: zużycie energii pierwotnej, emisja gazów cieplarnianych, udział energii ze źródeł odnawialnych w końcowym zużyciu energii brutto. $Z$ kolei w obszarze wzrostu inteligentnego zastosowano wskaźniki: nakłady na działalność badawczo-rozwojową (\% PKB), osoby w wieku 30-34 lata posiadające wyższe wykształcenie, młodzież niekontynuująca nauki. W trzecim obszarze wykorzystano wskaźnik zagrożenia ubóstwem lub wykluczeniem społecznym - ogółem, wskaźnik zatrudnienia osób w wieku 20-64 lata - ogółem ${ }^{3}$. Na podstawie obliczonego syntetycznego wskaźnika stworzono ranking państw UE w realizacji Strategii „Europa 2020” w latach 2010 i 2014.

W tabeli 1 (dla roku 2010) oraz w tabeli 2 (dla roku 2014) przedstawiono kształtowanie się wartości syntetycznego wskaźnika realizacji założeń Strategii „Europa 2020" i miejsca w rankingu poszczególnych państw UE osiągnięte w obszarze wdrażania tej strategii ${ }^{4}$.

Z analizy wartości syntetycznego wskaźnika wynika, że w roku 2010 liderami w obszarze realizacji Strategii „Europa 2020” były: Szwecja, Finlandia, Dania oraz Austria. Aktywność tych krajów w polityce zrównoważonego rozwoju spowodowała, że pozostały one również liderami włączania założeń strategii w roku 2014. Jednakże w nowym rankingu Dania znajduje się na drugim, a Finlandia na trzecim miejscu.

W porównaniu z rokiem 2010 w 2014 r. 10 państw poprawiło swoje miejsce w rankingu realizacji założeń strategii. Należą do nich: Czechy, Dania, Litwa, Łotwa, Malta, Polska, Rumunia, Słowenia, Słowacja i Węgry. Z kolei 14 państw pogor-

${ }^{3}$ Zastosowane wskaźniki są względnie niezależne. Powiązania przyczynowo-skutkowe sprawdzono, obliczając współczynnik korelacji Pearsona.

${ }^{4}$ Większa wartość wskaźnika świadczy o lepszej pozycji państwa w obszarze realizacji założeń strategii. 
Tabela 1. Kształtowanie się wartości syntetycznego wskaźnika realizacji założeń Strategii „Europa 2020 " oraz miejsca w rankingu poszczególnych państw UE osiągnięte w wyniku wdrażania tej strategii w roku 2010

\begin{tabular}{|l|c|c|l|c|c|}
\hline \multicolumn{1}{|c|}{ Kraj } & Wskaźnik & Ranking & \multicolumn{1}{c|}{ Kraj } & Wskaźnik & Ranking \\
\hline Austria & 0,549 & 4 & Litwa & 0,328 & 14 \\
\hline Belgia & 0,412 & 10 & Luksemburg & 0,411 & 11 \\
\hline Bułgaria & 0,033 & 27 & Lotwa & 0,279 & 17 \\
\hline Chorwacja & 0,277 & 18 & Malta & 0,042 & 28 \\
\hline Cypr & 0,249 & 21 & Niemcy & 0,511 & 5 \\
\hline Czechy & 0,350 & 13 & Polska & $\mathbf{0 , 2 7 0}$ & $\mathbf{1 9}$ \\
\hline Dania & 0,641 & 3 & Portugalia & 0,289 & 16 \\
\hline Estonia & 0,386 & 12 & Rumunia & 0,143 & 26 \\
\hline Finlandia & 0,650 & 2 & Słowacja & 0,266 & 20 \\
\hline Francja & 0,483 & 7 & Słowenia & 0,502 & 6 \\
\hline Grecja & 0,234 & 22 & Szwecja & 0,792 & 1 \\
\hline Hiszpania & 0,207 & 24 & Węgry & 0,206 & 25 \\
\hline Holandia & 0,450 & 8 & Wielka Brytania & 0,426 & 9 \\
\hline Irlandia & 0,319 & 15 & Włochy & 0,217 & 23 \\
\hline
\end{tabular}

Źródło: obliczenia własne na podstawie danych z Eurostatu [http:/www.epp.eurostat.ec.europa.eu].

Tabela 2. Kształtowanie się wartości syntetycznego wskaźnika realizacji założeń Strategii „Europa 2020 " oraz miejsca w rankingu poszczególnych państw UE osiągnięte w wyniku wdrażania tej strategii w roku 2014

\begin{tabular}{|l|c|c|l|c|c|}
\hline \multicolumn{1}{|c|}{ Kraj } & Wskaźnik & Ranking & \multicolumn{1}{c|}{ Kraj } & Wskaźnik & Ranking \\
\hline Austria & 0,619 & 4 & Litwa & 0,490 & 7 \\
\hline Belgia & 0,426 & 12 & Luksemburg & 0,422 & 13 \\
\hline Bułgaria & 0,069 & 28 & Lotwa & 0,413 & 14 \\
\hline Chorwacja & 0,281 & 20 & Malta & 0,075 & 27 \\
\hline Cypr & 0,237 & 22 & Niemcy & 0,496 & 6 \\
\hline Czechy & 0,429 & 11 & Polska & $\mathbf{0 , 3 4 6}$ & $\mathbf{1 7}$ \\
\hline Dania & 0,685 & 2 & Portugalia & 0,293 & 19 \\
\hline Estonia & 0,386 & 15 & Rumunia & 0,110 & 25 \\
\hline Finlandia & 0,645 & 3 & Słowacja & 0,318 & 18 \\
\hline Francja & 0,487 & 8 & Słowenia & 0,498 & 5 \\
\hline Grecja & 0,100 & 26 & Szwecja & 0,805 & 1 \\
\hline Hiszpania & 0,143 & 24 & Węgry & 0,276 & 21 \\
\hline Holandia & 0,467 & 9 & Wielka Brytania & 0,448 & 10 \\
\hline Irlandia & 0,353 & 16 & Włochy & 0,202 & 23 \\
\hline
\end{tabular}

Źródło: obliczenia własne na podstawie danych z Eurostatu [http:/www.epp.eurostat.ec.europa.eu]. 
szyło swoją pozycję w rankingu. W tej grupie znalazły się: Belgia, Bułgaria, Chorwacja, Cypr, Estonia, Finlandia, Francja, Grecja, Holandia, Irlandia, Luksemburg, Niemcy, Portugalia, Wielka Brytania. Wśród państw, które w rankingu pozostały na tym samym miejscu, są: Austria, Hiszpania, Szwecja i Włochy.

W pierwszej dziesiątce państw UE, które osiągnęły najlepsze wyniki w realizacji założeń strategii, znalazły się:

- w roku 2010: Szwecja, Finlandia, Dania, Austria, Niemcy, Słowenia, Francja, Holandia, Wielka Brytania, Belgia;

- w roku 2014: Szwecja, Dania, Finlandia, Austria, Słowenia, Niemcy, Litwa, Francja, Holandia, Wielka Brytania.

W roku 2014 do grupy 10 państw wiodących w realizacji założeń strategii dołączyła Litwa. W przypadku tego kraju znacznie poprawiły się parametry w obszarze: - włączenia społecznego (wzrosło zatrudnienie z 64,3\% do 71,8\%; zmniejszyło się zagrożenie ubóstwem i wykluczeniem społecznym: z 34\% do 27,3\%),

- rozwoju inteligentnego (wzrosły nakłady na badania i rozwój: z 0,78\% do 1,03\%; zmniejszyła się wartość wskaźnika młodzieży niekontynuującej nauki: z 7,9\% do 5,9\%; wzrósł wskaźnik osób w wieku 30-34 lata posiadających wykształcenie wyższe: z $43,8 \%$ do $53,3 \%$ ),

- klimatu i energii (spadła emisja gazów cieplarnianych5: z 42,62 do 40,51; zmniejszyło się zużycie energii pierwotnej ${ }^{6}$ : z 242,2 do 202,5; wzrósł udział energii ze źródeł odnawialnych w końcowym zużyciu energii brutto: z 19,8\% do 23,9\%).

Łotwa jest kolejnym państwem, które znacznie podwyższyło swoje miejsce w rankingu realizacji założeń strategii. W obszarze wzrostu inteligentnego: wzrosły nakłady na badania i rozwój (z 0,61\% do 0,69\%),zmniejszył się odsetek młodzieży niekontynuującej nauki (z 12,9\% do 8,5\%) oraz zwiększyła się wartość wskaźnika osób w wieku 30-34 lata mających wyższe wykształcenie (z 32,6\% do 39,9\%). W obszarze energii i klimatu: spadła emisja gazów cieplarnianych (z 47,8 do 44,04); zmniejszyło się zużycie energii pierwotnej (z 260,2 do 215,7) oraz wzrosło wykorzystanie energii ze źródeł odnawialnych (z 30,4\% do 38,7\%). W obszarze włączenia społecznego wzrosło zatrudnienie (z $64,3 \%$ do $70,7 \%$ ) oraz spadło zagrożenie ubóstwem i wykluczeniem społecznym (z 38,2\% do 32,7\%).

Także w przypadku Węgier wystąpił stosunkowo duży wzrost pozycji w rankingu wdrażania założeń Strategii „Europa 2020”. W obszarze włączenia społecznego zwiększyło się zatrudnienie (z 59,9\% do 66,7\%), w obszarze wzrostu inteligentnego zwiększone zostały nakłady na badania i rozwój (z 1,15\% do 1,36\%) oraz zwiększył się odsetek osób w wieku 30-34lata z wyższym wykształceniem (z 26,1\% do 34,1\%). W obszarze klimatu i energii spadła emisja gazów cieplarnianych (z 69,98 do 61,02), zmniejszyło się również zużycie energii pierwotnej (z 261,5 do 217,7) oraz wzrosło zużycie energii ze źródeł odnawialnych(z 8,6\% do 9,5\%).

\footnotetext{
$5[1990=100]$.

${ }^{6}$ [kgoe na 1000 EUR].
} 
W Czechach poprawiła się sytuacja w obszarze:

- włączenia społecznego (wzrost zatrudnienia z 70,4\% do 73,5\%),

- rozwoju inteligentnego (nakłady na badania i rozwój wzrosły z 1,34\% do 1,97\%; zwiększyła się wartość wskaźnika osób w wieku 30-34 lata posiadających wyższe wykształcenie z $20,4 \%$ do $28,2 \%$ ),

- klimatu i energii (wzrósł udział energii ze źródeł odnawialnych z 9,5\% do 13,4\%; spadła emisja gazów cieplarnianych: z 70,64 do 63,45; nastąpił również spadek zużycia energii pierwotnej: z 285,7 do 256,3).

Na Słowacji poprawa parametrów w realizacji Strategii „Europa 2020” wystąpiła w obszarze:

- energii i klimatu (spadła emisja gazów cieplarnianych: z 105,51 do 89,23; zmniejszyło się zużycie energii pierwotnej: z 202,6 do 184,5; wzrósł udział energii ze źródeł odnawialnych z 20,5\% do 21,9\%),

- w obszarze wzrostu inteligentnego (wzrosły nakłady na badania i rozwój: z 0,62\% do 0,88\%, zwiększyła się wartość wskaźnika osób w wieku 30-34 lata posiadających wyższe wykształcenie: z 22,1\% do 26,9\%),

- włączenia społecznego (zmniejszyło się zagrożenie ubóstwem i wykluczeniem społecznym: z 20,6\% do 18,4\%; wzrosło zatrudnienie: z 64,6\% do 65,9\%).

Polska jest również w grupie państw, które poprawiły swoją pozycję w rankingu wprowadzania założeń strategii. W obszarze włączenia społecznego wzrosło zatrudnienie (z 64,3\% do 66,5\%), zmniejszyło się zagrożenie ubóstwem i wykluczeniem społecznym (z 27,8\% do 24,7\%). W obszarze klimatu i energii zaznaczył się spadek emisji gazów cieplarnianych (z 86,1 do 80,68), zmniejszyło się zużycie energii pierwotnej (z 278,3 do 233,3) oraz wzrosło wykorzystanie energii ze źródeł odnawialnych (z $9,2 \%$ do $11,4 \%)$. Z kolei w obszarze wzrostu inteligentnego zwiększyły się nakłady na badania i rozwój (z $0,72 \%$ do $0,94 \%$ ) oraz wzrósł odsetek osób w wieku 30-34 lata posiadających wyższe wykształcenie (z 34,8\% do 42,1\%).

$\mathrm{Z}$ analizy kształtowania się wartości syntetycznego wskaźnika wynika, że szczególny spadek w rankingu państw wystąpił w przypadku Estonii, Portugalii i Grecji. W przypadku Estonii: w obszarze klimatu i energii wzrosła emisja gazów cieplarnianych (z 49,97 do 52,87), w obszarze włączenia społecznego zwiększyło się zagrożenie ubóstwem i wykluczeniem społecznym (z 21,7\% do 26\%), a w obszarze wzrostu inteligentnego spadły nakłady na badania i rozwój (z 1,58\% do 1,45\%) i zwiększył się odsetek młodzieży niekontynuującej nauki (z 11\% do 11,4\%). Portugalia charakteryzuje się tym, że w rozpatrywanym okresie w obszarze wzrostu inteligentnego spadły nakłady na badania i rozwój (z 1,53\% do 1,29\%), a w obszarze włączenia społecznego zmniejszyło się zatrudnienie (z 70,3\% do 67,6\%) oraz wzrosło zagrożenie ubóstwem i wykluczeniem społecznym (z 25,3\% do 27,5\%). Z kolei w Grecji pogorszenie sytuacji wystąpiło w obszarze włączenia społecznego, w którym spadło zatrudnienie (z 63,8\% do 53,3\%) oraz wzrosło zagrożenie ubóstwem i wykluczeniem społecznym (z 27,7\% do $36 \%$ ). 
W tabeli 3 przedstawiono państwa, które pogorszyły swoją pozycję w rankingu, oraz rodzaje wskaźników, których niekorzystne zmiany w wartości przyczyniły się do spadku danego kraju w rankingu państw realizujących założenia Strategii „Europa $2020 "$.

Tabela 3. Rodzaje wskaźników, których niekorzystne zmiany w wartości przyczyniły się do spadku danego kraju w rankingu państw realizujących założenia Strategii „Europa 2020”

\begin{tabular}{|l|l|}
\hline \multicolumn{1}{|c|}{ Niekorzystna zmiana wskaźnika } & \multicolumn{1}{c|}{ Kraj } \\
\hline Wzrost emisji gazów cieplarnianych & Estonia \\
\hline Spadek nakładów na badania i rozwój & $\begin{array}{l}\text { Estonia, Finlandia, Irlandia, Luksemburg, } \\
\text { Portugalia }\end{array}$ \\
\hline Wzrost odsetka młodzieży nikontynuującej nauki & Bułgaria, Estonia \\
\hline $\begin{array}{l}\text { Spadek odsetka osób w wieku 30-34 lata } \\
\text { posiadających wyższe wykształcenie }\end{array}$ & Belgia, Finlandia \\
\hline Spadek zatrudnienia osób w wieku 20-64 lata & $\begin{array}{l}\text { Belgia, Chorwacja, Cypr, Grecja, Holandia, } \\
\text { Portugalia }\end{array}$ \\
\hline $\begin{array}{l}\text { Wzrost zagrożenia ubóstwem i wykluczeniem } \\
\text { społecznym }\end{array}$ & $\begin{array}{l}\text { Belgia, Cypr, Finlandia, Grecja, Holandia, } \\
\text { Irlandia, Luksemburg, Niemcy, Wielka Brytania }\end{array}$ \\
\hline
\end{tabular}

Źródło: opracowanie własne na podstawie danych z Eurostatu [http:/www.epp.eurostat.ec.europa.eu].

\section{Zakończenie}

Stworzenie syntetycznego wskaźnika dla Strategii „Europa 2020” umożliwiło ocenę stanu realizacji założeń tej strategii przez poszczególne państwa Unii Europejskiej. Zmierzenie postępu wdrażania założeń strategii przy jednoczesnym uwzględnieniu wszystkich obszarów ułatwiło dokonanie rankingu tych państw w latach 2010 i 2014. Na podstawie przeprowadzonych obliczeń wynika, że zarówno w roku 2010, jak i 2014 liderami w zakresie realizacji celów Strategii „Europa 2020” są Szwecja, Dania, Finlandia i Austria. Wysokie miejsce tych państw w rankingu uwarunkowane jest osiąganiem wysokiej pozycji w poszczególnych obszarach strategii.

Zadawalające jest, że 9 państw, które w roku 2010 były w pierwszej dziesiątce krajów najlepiej wdrażających założenia strategii, w rankingu w roku 2014 pozostało nadal w pierwszej dziesiątce. W przypadku Litwy wystąpił znaczny wzrost pozycji w rankingu (o 7 miejsc), co wpłynęło na znalezienie się tego kraju w pierwszej dziesiątce państw najlepiej realizujących cele Strategii „Europa 2020”. Istotne wzrosty w rankingu wystąpiły w przypadku Węgier (z 25 na 21 miejsce) i Czech (z 13 na 11 miejsce). Również Polska poprawiła swoją pozycję w rankingu (z 19 na 17 miejsce).

Znaczniejsze spadki pozycji w rankingu państw zaznaczyły się tylko w przypadku trzech krajów: Grecji (z 22 na 26 miejsce), Portugalii (z 16 na 19 miejsce) oraz Estonii (z 12 na 15 miejsce). Przyczyną tej sytuacji był spadek nakładów na badania i rozwój (Estonia, Portugalia), spadek zatrudnienia (Portugalia, Grecja), wzrost za- 
grożenia ubóstwem i wykluczeniem społecznym (Grecja), wzrost liczby młodzieży niekontynuującej nauki (Estonia) i wzrost emisji gazów cieplarnianych (Estonia).

Na podstawie przeprowadzonych badań można wyodrębnić grupę państw, które w rankingu charakteryzowały się niskimi miejscami. Można do nich zaliczyć: Bułgarię, Maltę, Grecję, Rumunię, Cypr, Węgry i Hiszpanię. Kraje te w porównaniu z pozostałymi państwami UE charakteryzują się niezbyt korzystnymi wartościami wskaźników monitorujących realizację Strategii „Europa 2020”. Szczególnie niepokojące jest pogłębianie się zjawiska trudności ze zwiększaniem zatrudnienia oraz wzrostu ubóstwa i wykluczenia społecznego. W państwach tych obserwuje się znaczne ograniczenie nakładów na badania i rozwój. Również w realizacji celu ,20/20/20” w zakresie klimatu i energii nie osiągają one zadowalających efektów.

\section{Literatura}

Bigg T., 2011, Development governance and the green economy: A matter of life and death?, Review of Policy Research, vol. 28, s. 459-465.

Blengini A., Busto G., Fantoni M., Fino D., 2012, Eco-efficient waste glass recycling: Integrated waste management and green product development through LCA, Waste Management, no. 32, s. 1000-1008 .

Brouhle K., Graham B., Harrington D.R., 2013, Innovation under the climate Wise program, Resource and Energy Economic, no. 35, s. 91-112.

Coddington W., 1993, Environmental marketing. Positive strategies for reaching the green consumer, McGraw-Hill, New York.

Common M., Stagl S., 2005, Ecological economics. An introduction, Cambridge University Press, New York.

Dziawgo E., 2014, Real options in the assessment of the company's pro-ecological investments, Copernical Journal of Finance \& Accounting, no. 3, s. 61-73.

Dziawgo L., Dziawgo E., 2016, Ecological evolution of financial market: ecologically responsible investment, [w:] N.H. Bilgin, H. Danis, E. Demir and U. Can (eds.), Business Challenges in the Changing Economic Landscape, Springer, s. 167-178.

Europe 2020: A strategy for smart, sustainable and inclusive growth, European Commission, KOM $2010(3.03 .2010)$.

Eurostat, Energy, transport and environment indicators, 2016, Luxemburg: Publications Office of the European Union.

Figge F., Hahn T., 2012, Is green and profitable sustainable? Assessing the trade-off between economic and environmental aspects, Journal Production Economics, no. 140, s. 92-102.

Hellwig Z., 1968, Zastosowanie metody taksonomicznej do typologicznego podziału krajów ze względu na poziom rozwoju oraz zasoby i strukturę wykwalifikowanych kadr, Przegląd Statystyczny, nr 4, s. 307-327.

Hinrichs-Rehlwes R., 2013, Renewable energy: Paving the way towards sustainable energy security Lessons learnt from Germany, Renewable Energy, no. 4, s. 10-14.

http:/www.epp.eurostat.ec.europa.eu (1.03.2017).

Jänicke M., 2012, Green growth: from a growing eco-industry to economic sustainability, Energy Policy, no. 48 , s. 13-21. 
Piontek B., Piontek F., Piontek W., 2002, Ekorozwój i narzędzia jego realizacji, Wydawnictwo Ekonomia i Środowisko, Białystok.

Poskrobko B., 1998, Zarzązanie środowiskiem, PWE, Warszawa.

Stern N., 2007, The economics of climate change. The Stern Review, Cambridge University Press, Cambridge.

Ten priorities for Europe, 2015, Publications Office of the European Union, Luxembourg.

The European Union climate action, 2014, Publications Office of the European Union, Luxemburg.

The state of Nature in the European Union, 014, Publications Office of the European Union, Luxemburg.

Yi H., 2013, Clean energy policies an green jobs: An evaluation of green jobs in U.S. metropolitan areas, Energy Policy, no. 56, s. 644-652. 